\title{
Analyzing mechanics of rock breaking under conditions of hydromechanical drilling
}

\author{
Andrii Ihnatov ${ }^{1 * \otimes}$ (1) \\ ${ }^{1}$ Dnipro University of Technology, Dnipro, 49005, Ukraine \\ *Corresponding author: e-mail A_3000@i.ua, tel. +380567463232
}

\begin{abstract}
Purpose is to substantiate design factors and technological parameters of next-generation facilities of hydromechanical drilling basing upon the determined features of interaction between breaking pellets and rock mass.

Methods. The studies of directionality features and bottomhole processes for rock mass breaking have been carried out using the current analytical methods and laboratory experiments. Among other things, certain mathematical and physical simulation techniques, methods of theoretical processing and interpretation of the research results under SolidWorks, Statgraphics, and Mathcad environments, and a number of relevant instruments and materials have been applied. Following their technological sequence, the well bottomhole rock-breaking processes were simulated using a special laboratory stand equipped with a control-and-measuring unit (inclusive of a flowmeter, manometer, tachometer, and coordinate spacer among other things).
\end{abstract}

Findings. Application perspectiveness of the combined techniques for rock breaking has been proved. Structural designs of the next-generation facilities for well drilling have been proposed. The pellet-impact drilling features have been analyzed from the viewpoint of its significant dynamic component during the rock mass breaking. Nature of the effect of breaking load rate on the results of bottomhole deformation processes has been identified. Efficiency of the proposed scheme to improve pellet-impact drilling based upon maximum use of a well bottomhole deformed by pellets has been proved. Measures to increase technical and technological indicators of pellet drilling have been considered. Requirements for the conditions stabilizing operation of a collar of the pellet-impact device have been outlined. Further research tendencies have been specified.

Originality. It has been determined that compliance with specific geometrical and hydromechanical ratios, corresponding to the stable mode of a well sinking, is the factor required for reliable operation of hydromechanical drilling facilities.

Practical implications. The results of stand-based tests as well as analytical studies may become the foundations to develop efficient engineering decision for hydromechanical well drilling with high technical and economic indicators. The data, concerning bottomhole rock breaking processes, are the basic ones to work out rational standard parameters of well sinking processes.

Keywords: well, drilling, bottomhole, rotational velocity, penetration rate

\section{Introduction}

\subsection{The problem statement}

Classification analysis of the current stage of drilling engineering and its key component being rock mass breaking proves literally the availability of numerous methods and techniques to shape a well shaft. Among other things, they rely upon technical and technological features of tool support [1]-[4]. Such a situation results from a variety of geological and engineering problems solved for drilling. The following are the main ones: to obtain qualitative core samples of rock formations and productive formations; and development of a reliable serviceable channel for mineral extraction.

Taking into consideration high capital intensity of a drilling cycle, determined also by considerable depths and rela- tive to them localization of the basic production operations concerning well construction, researchers are focused on the development of such drilling techniques characterized by maximum continuity and independence [2], [3]. The abovementioned can be commented as follows: any drilling technique should match stability criteria of a rock-breaking tool making it possible to save time for auxiliary operations connected with the tool interchange; moreover, operations by corresponding tool should be excluded from the influence of factors preventing from strict adherence to operation practices. To some extent, achievement of the goals is held back by objective manifestation of rather wide range of physicomechanical and chemical characteristics of rock mass in the process of its deformation [5]. The following should also be added: on the whole, drilling process depends inevitably

Received: 1 November 2020. Accepted: 3 September 2021. Available online: 22 September 2021

(C) 2021. A. Ihnatov

Published by the Dnipro University of Technology on behalf of Mining of Mineral Deposits. ISSN 2415-3443 (Online) | ISSN 2415-3435 (Print)

This is an Open Access article distributed under the terms of the Creative Commons Attribution License (http://creativecommons.org/licenses/by/4.0/),

which permits unrestricted reuse, distribution, and reproduction in any medium, provided the original work is properly cited. 
upon certain technological restrictions set up by the requirements for a well as a capital mine working and upon clear range of the equipment and tool capabilities.

\subsection{Analysis of recent studies and publications}

From a viewpoint of practical issues of the mining sector, factual information concerning prevailing tendencies demonstrates such an important point that the majority of the available rock cutting techniques (inclusive of those ones applied for well drilling) are based upon mechanical separation of rock mass into certain fragments of one size or another. The process takes place under the action of local disturbing forces exceeding the internal rock forces [2], [3]. Under the specified conditions, rock efforts result from the action of hard tools, hydraulic flows, and the developed waves and fields of diverse nature [6]. In this context, further progress and improvement are mainly accounted for rock-breaking tools if general approaches to the idea of the applied drilling techniques have been maintained. Such an orientation of the activities has helped make real progress in the extension of tool efficiency, rationalization of a structure sequence, achievement of optimum indices of penetration rate, and certain substantiated simplification of a rock-breaking tool design as well as operating parameters of the tool [7], [8].

However, problematics of the listed issues is demonstrated convincingly in the complexity and sometimes impossibility to achieve the integrated efficiency of medium-hard rock cutting aside from hard and solid ones [9]. Rock formations, characterized by frequent hardness changes, are challenging for the process of a well shaft shaping [10].

\subsection{Singling-out a previously unsolved part of the general problem}

Physical manifestation of deformations being available in rock mass (i.e. buckling, chipping, cutting, crushing etc.) [6] is a distinctive feature of the majority of production methods of well drilling resulting in its fragmentation. Nevertheless, the examples cannot limit possible alternatives of a well bottom advance within the rock mass. Such breaking techniques, being predominantly a physical tendency, are applied in practice to different extents [8]. They are based upon internal forces and connections participating in the process under the effect of temperature, electromagnetic, and other fields inclusive of those ones provoking radical changes in the rock mass conditions (for instance, change in its aggregate state).

At the same time, common feature of the abovementioned techniques is as follows. Despite the fact that in certain cases they are quite efficient, their implementation is complicated and rock characteristics restrict them violently. The latter is far from being typical for rock disintegration. However, by no means such problem statement can be considered as the basis for exclusion of physical methods from the techniques to shape a well bottom. The matter is that numerous theoretical studies and drilling practices have substantiated the following: extremely high breakage indices (mainly, it concerns hard rock) can be achieved while combining different deformation types and their development techniques. In our case, it is combination between the mechanical action of specific tools and hydraulic energy of directed liquid flows [11].

\subsection{Purpose of the paper and problem definition}

It is required to substantiate both structural and technological parameters of the improved hydromechanical drilling facilities relying upon the determined features of interaction between breaking pellets and rock mass.

Well penetration process, divided into separate trips, includes numerous activities not directly associated with bottomhole disintegration. Well construction (particularly, in terms of hard rock) initiates the necessity of comparatively frequent pulling out of drill string including those cases when it is required to replace worn tool from its bottom end [12]. The factor encouraged development of devices and technologies helping prolong a trip owing to use of removable rock-breaking tool (it is transported inside a drill string without its surfacing); and use of hard pellets filling (shot) into a well through its collar or transporting to the bottomhole with the help of a liquid flow. Implementation of the idea of the last method made it possible to identify its key advantages and disadvantages [11], [13]. Meanwhile, analysis of scientific data and industrial data as well as laboratory experiments and theoretical studies has shown significant potential of hydromechanical method, almost ignored by the current drilling practices.

\section{Materials and methods}

According to the defined problem, pellet-impact drilling, first applied for well construction by researchers from the USA, is a basic principle of the proposed method [14]. However, the facilities, designed for implementation of the efficient drilling technique, have demonstrated their limited application and significant imperfection during the operation. The last circumstance initiated the search for new perfect designs of facilities to be applied for hydromechanical drilling. The device, shown in Figure 1, meets optimally the bottomhole factors of a well construction designed by the Department of Oil-and-Gas Engineering and Drilling (OGED) of the Dnipro University of Technology (DUT) [15]. The device operates as follows: when liquid circulation arises within the internal share of a body 1 , motion of rock-breaking pellets 3 starts destructing the bottomhole. In a well bottom zone the liquid flow is divided into two parts. One of them raises up to an impact apparatus 2 together with the pellets; another one, containing muck, get to the annular space between the edge and body of a rockbreaking ring 4 , and bottomhole and well walls respectively. The muck is removed through a wash-out port 8 . A ring 4 is required to shape rectangular profile of the bottomhole owing to disintegration of its curvilinear walls which origination depends upon processing a drilling route, and results in the decreased penetration rate or in the complete penetration process. A liquid flow places and houses pellets 3 within catchers 5 contained by ring 4 in the lower part.

Constant rotation of ring 4 results from the available turbine set within the upper part. The turbine set is driven by a liquid which flow is divided into two streams while leaving a shaft 9 . One of the flows moves to a jet device. Being rotated by $180^{\circ}$, another one moves to a turbine. Then it migrates to a space between a well walls and the device body through holes 10. Another possible alternative to disintegrate rock using hard pellets is the improvement of a shot drilling device (Fig. 2) [16]. To compare with the previous one, the device makes it possible to construct wells with core sampling. 


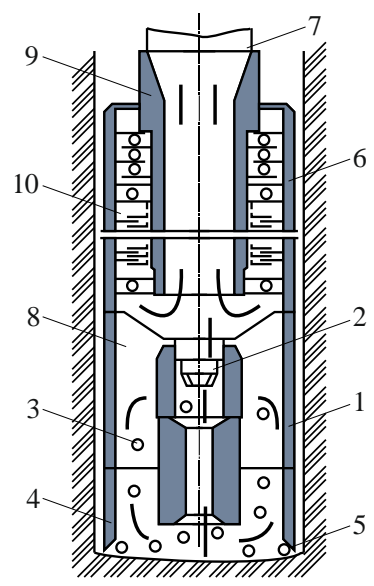

Figure 1. A facility for pellet-impact drilling

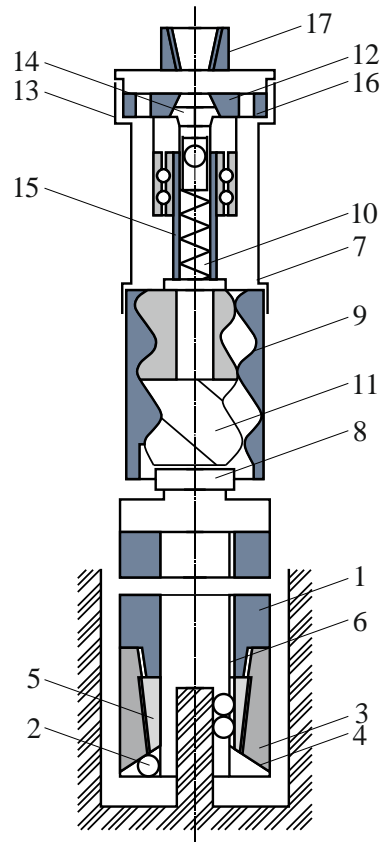

Figure 2. A facility for shot drilling

The facility operates as follows: liquid rotation initiates turning motion of a propelling screw 7 which torque is transferred to shots 3 through adapter 8 and consequently, through a core catcher housing 1 and a rock ring 2 . The shots interact with rock and disintegrate it. The through grooves 4 being of variable height lowering from an axis to a ring 2 periphery are required to place and house consistently shots 3 , and transfer reliably torque to them. Shots 3 rub away during drilling. Then, they separate themselves gradually from grooves 4 . The rubbed shots are replaced by larger and more capable ones from vertical collector grooves 6 . The mechanism, delivering new shots and removing the rubbed ones, excludes possibility of accumulation of the shots within the external space of a well and its unreasonable development. After the device lowering, shots 3 are introduced superficially into a drilling liquid flow. In this context, they go freely through a drill string. Then, they get to internal cavity of a core receiver through a pin 17 , a flange 12, a flexible shaft 9 (with a collet valve 14 ), and a hollow rotor 11 placing consequently within grooves 6 . When the facility is being erected on a well bottom, its slotted connectors 13 interlock; and a flange 12 moves down, shutting a collet valve 14 . The pro- cedure varies a motion direction of drilling fluid to pass through circulation channels 16 only initiating putting into operation a propelling screw 7. Spring 15, placed in the internal space of a flexible tubular shaft 9 , is required to fasten reliably a collet valve while its closing. High rotation frequencies of a ring 2 with shots 3 as well as its multicontact with a bottomhole favour the most efficient conditions of rock breakage required right for shot drilling. Owing to the abovementioned, both procedure and orientation of elementary act of rock fragmentation vary; penetration rate increases respectively. Core breakoff and its holdup within a core catcher body are performed at the expense of motor 7 cessation as well as left rotation of the drill string with the device. In this case, significant friction between a core column and shots 3, located in collector grooves, a cutaway circular core breaker 5 is screwed down on the thread with its simultaneous join within the cut area and corresponding decrease in the internal diameter. The abovementioned will result in its join and tight core pressing through shots 3. Several rotations of a drill string are sufficient to perform the breakoff stipulating high stresses within the core as well as its chipping.

The experiments, studying technological characteristics of orientation and behaviour of face breakage processes in terms of operation of the advanced hydromechanical drilling facilities, have been carried out with the use of the current analytical methods and laboratory tests. Among other things, certain mathematical and physical simulation techniques; methods of theoretical processing and interpretation of the research results under SolidWorks, Statgraphics, and Mathcad environments; and a number of relevant instruments and materials have been applied [17]-[19].

The process of solving problems of optimum planning of laboratory and analytical experiments involved following basic stages: parametrization and substantiation of the planned model; the required output data preparation and analysis; evaluation of the model; and result generation [20].

Following their technological sequence, the bottomhole breaking processes were simulated using a special laboratory stand equipped with a control-and-measuring unit (inclusive of a flowmeter, manometer, tachometer, and coordinate spacer among other things).

\section{Results and discussion}

Practices of drilling operations is the objective index making it possible to evaluate to the fullest extent possible the potential efficiency of certain innovative or rationalized design and engineering solutions [21]. At the same time, the commonly-known fact is out in the open: manufacturing complexity as well as engineering support of certain (among other things, design components) of numerous innovative drilling methods and techniques is the key constraining factor preventing from their general industrial application. The matter is that the design components also often need radical restructuring of the whole basic process of a well construction which is not always possible and economically feasible in terms of the available minimum financing level of geological and mining sector. The factor, being among the most influential ones, was taken as a principle to modernize hydromechanical drilling.

Significant diameter variations and constant changes in the bottomhole conditions, depending upon gradual penetration of rock mass, impact mainly all corresponding proces- 
ses [22], [23]. In terms of the factors, implementation of the design mode parameters for the development of rock-cutting tools, is under the heaviest influence.

To a great extent, downhole tool efficiency depends upon compliance with rational norms of axial load on it [24]. However, increase in penetration levels up extremely the possibility to transmit the required load effort to the tool due to large contact area between a drill string and well walls stipulated by design arrangement of a drill string, characteristics of environment, operation mode of a drill string in a well, and natural or artificial borehole curving.

It is also important that the manufacturing of a rockbreaking tool is connected with consumption of critical materials and expensive ones which use cannot always correspond positively to the final results of drilling as a technological operation [25]. Moreover, design of core tools with large diameters is not mastered technically (and even baselessly) [26] imposing extra constraints on geological and engineering conditions of the relevant well construction.

A drilling technique, implemented with the help of destructive pellets, most correspond to such a supercomplex (at some points) problem of compliance with the restrictive and fundamental features of innovative development of well construction methods [11]-[13].

The designs of facilities, proposed by the experts from OGED of the Dnipro University of Technology, combine the most positive characteristics making it possible to avoid or minimize the available disadvantages as for the mechanism of rock breaking on a bottomhole. The process rationalization, inclusive of substantiation of all its factors, will help increase significantly effectiveness of the methods which may become a progressive alternative to the current low income-earning and cost-plus techniques.

Rock breaking efficiency, involving use of the considered drilling facilities being united as hydromechanical ones, will be identified with the help of characteristics of materials to be broken (usually, the index is objective one); structural features of rock-cutting tools (i.e. pellets, shots as well as specific rings to hold the latter with adequate geometric and mechanical characteristics); and drilling mode factors (i.e. a value of the cutting force, its direction, and rate of reaction).

Introduction of a mechanical rock-breaking tool, intended to avoid the substantial disadvantages of well construction with the use of pellets, is the innovative structural characteristic changing fundamentally the downhole processes of pellet-impact drilling [14]. Since rock-cutting ring is the key tool of the facilities, all its structural components as well as their mechanism of interaction with pellets and rock mass as well as operation drilling schedules should be substantiated thoroughly and harmonized with a wide range of properties of contacting materials.

First of all, origination of numerous drilling techniques as well as rock breaking tools depends upon the fact that rocks have a set of interconnected properties defining their physicomechanical characteristics. Rock strength and hardness are the basic characteristics when a direct instrumental action on rock mass takes place. It should be mentioned that if metal alloys and various natural or synthetic materials are applied as rock cutting elements, then their designs and operation schedules make it possible to cut rock mass with different performance indicators correlating with the diversity of manifestation of rock properties.
A rock-breaking scope and its power intensity may be assumes as a representative qualitative and quantitative measure of efficiency. Power intensity can be evaluated using amount of the broken rock or a degree of the tool penetration into the rock. Moreover, it is quite clear that the penetration is not the purpose. The task is to separate as much rock as possible from the formation during the operation.

According to the abovementioned, it is usual to separate such forms of rock failure as surface form, fatigue form, and volumetric one. The volumetric rock failure type, being the most efficient one, is characterized by a large propagation of deformations within the rock mass resulting in the formation of holes.

Analysis of the production data as well as the laboratory ones makes it possible to confirm that as for the failure forms well penetration process is identified by proficient consideration of physicomechanical behaviour of rock mass.

To compare with other drilling techniques, hydromechanical (i.e. pellet-impact) method is first characterized by the disproportionately high velocities of load application (with the help of pellets) to rocks. The velocities are $60 \mathrm{~m} / \mathrm{s}$ and more. In terms of a failure scheme, it can be comparable with roller drilling [2] and [27] if only bits operate to crush and shear. The fact differs the bits from the viewpoint of significant dynamics of load application being rather efficient as for the predetermination of volumetric form of rock failure since it is extremely important for hard rock.

Moreover, comparison of impact velocities, shown in Table 1, proves that in terms of pellet-impact drilling, the latter exceeds greatly that one of roller bit one.

Table 1. Impact velocity while using cutting structure of roller bits

\begin{tabular}{ccc}
\hline & \multicolumn{2}{c}{ Standard size of a bit } \\
\cline { 2 - 3 } Minimal required period of & $190.5 \mathrm{NU}-$ & $190.5 \mathrm{AUL}-$ \\
cutter tooth-rock contact, ms & $74 \mathrm{Y}-\mathrm{R} 30$ & $\mathrm{LS21G}-$ \\
& \multicolumn{2}{c}{ Imp08 } \\
\cline { 2 - 3 } & $0.54-0.41$ & - \\
\hline $6-8$ & - & $0.87-0.62$ \\
\hline $5-7$ & & \\
\hline
\end{tabular}

Two standard sizes of roller bits operating within the medium-hard and hard rock have been selected for the comparison taking into consideration values of minimal required period of cutter tooth-rock contact $\tau$ [28].

Relying upon the prerequisite that any drilling technique will be feasible if only it has minimum indices of power intensity as well as expenditures connected with bottom rock-cutting tools, it is possible to demonstrate substantial advantages of the methods being developed.

Well penetration velocity $u$, evaluated according Formula (1), is the objective drilling index helping estimate a degree of rational use of the drilling rig output inclusive of its downhole component [2]:

$u=\frac{1}{A_{v}} \cdot \frac{N}{F}$,

where:

$A_{v}$ - power intensity of rock failure process;

$N$ - capacity value supplied to a well bottom;

$F$ - well bottom area.

In turn, power intensity of a rock breaking process is identified using the formula: 


$$
A_{v}=\frac{W}{V},
$$

where:

$W$ - is power consumed to break the rock (in our case, it is the pellet-impact energy);

$V$ - volume of the broken rock.

In general, value of a pellet impact, is determined as follows:

$W=\frac{m v^{2}}{2}$,

where:

$m$ - mass of the pellet impacting a downhole;

$v$ - velocity of the pellets.
Analysis of Formulas (1)-(3) helps conclude the follo-wing: well penetration velocity is directly proportional to the downhole efficiency and reciprocally proportional to power intensity of breaking as well as a downhole area; and pellet-impact technique is characterized by sizeable energy values of impacts as well as their frequency ratio. Just at this spot it should be noted that the available methods, identifying the breaking process indices, are based upon the data obtained resulting from static (i.e. rather slow) penetration of indenters. Anyway, that cannot represent adequately the breaking mechanism essence in terms of substantial dynamics of load application. In the light of the above, OGED of the DUT has performed a number of studies to obtain the data concerning pellet velocity effect on the progress and results of deformation and breaking processes within the rock mass. Table 2 demonstrates their key data.

Table 2. Basic dynamic characteristics of rock breakage with the help of pellet impact

\begin{tabular}{|c|c|c|c|c|c|}
\hline \multirow[b]{2}{*}{$\begin{array}{l}\text { Rock under } \\
\text { study }\end{array}$} & \multirow{2}{*}{$\begin{array}{l}\text { Approximate rock } \\
\text { hardness through } \\
\text { intender, } \mathrm{N} / \mathrm{mm}^{2}\end{array}$} & \multicolumn{2}{|c|}{ Rock breaking conditions } & \multicolumn{2}{|c|}{ Results of the breaking process } \\
\hline & & $\begin{array}{l}\text { Nature of load } \\
\text { application }\end{array}$ & $\begin{array}{c}\text { Load application } \\
\text { velocity } v, \mathrm{~m} / \mathrm{s}\end{array}$ & $\begin{array}{c}\text { Depth of a breakdown } \\
\text { hole, } \mathrm{mm}\end{array}$ & $\begin{array}{l}\text { Approximate volume of a } \\
\text { breakdown hole } V_{p} 10^{3}, \mathrm{~mm}^{3}\end{array}$ \\
\hline \multirow{4}{*}{$\begin{array}{l}\text { Coarse-grained } \\
\text { granite }\end{array}$} & 4820 & static & - & 5.0 & 0.436 \\
\hline & \multirow{3}{*}{-} & \multirow{3}{*}{ dynamic } & 20 & 5.5 & 0.734 \\
\hline & & & 30 & 6.2 & 0.986 \\
\hline & & & 40 & 6.5 & 1.512 \\
\hline \multirow{4}{*}{$\begin{array}{l}\text { Fine-grained } \\
\text { granite }\end{array}$} & 5660 & static & - & 4.3 & 0.368 \\
\hline & \multirow{3}{*}{-} & dynamic & 20 & 4.8 & 0.646 \\
\hline & & & 30 & 5.3 & 0.859 \\
\hline & & & 40 & 6.1 & 1.406 \\
\hline
\end{tabular}

Data from Table 2 supports convincingly the idea of unconditional relationship between the velocity of load application $v$ scale of breaking processes in rocks. It is easy to see that gradual breaking penetration results in faster process of propagation of the breaking deformations. The fact can be interpreted by means of the available manifestations of tangential stresses. Studies have shown that they are quite important if load application is of dynamic nature. Metal patterns with $2.5 \mathrm{~mm}$ diameter and rounded necks were used as rock-breaking indenters for static loading, and metal pellets with $5 \mathrm{~mm}$ diameters were used for the dynamic one. It should be also noted that under the defined condition the process depends upon petrographic composition of rock; i.e. a complex of determinative components of mechanical characteristics of the latter should also involve size-consist in terms of similar mineralogical ratios.

Comparison of power consumption $W$ by rotary drilling and pellet-impact drilling shows that their balance differs greatly. Rotary drilling consumes power heavily for rock breaking within a downhole (determined by the nature of bit operation while interacting with rock mass); and for on-load rotation of drill pipes being nonavailable in case of pelletimpact drilling. In the context of pellet-impact drilling, power input for rock cutting $N$ is performed by means of hydraulic channel also fulfilling functions like in the context of rotary drilling. Hence, a pellet-impact device, incorporated by a turbine facility also equipped with a hydraulic supply channel, is quite an organic structural concept. On the one hand, it does not provoke significant increase in downhole efficiency losses; on the other hand, it helps localize the device drive right in front of the bottomhole zone. Moreover, impact acceleration $v$ increases significantly a bottomhole area covered by breaking zones (Fig. 3). The rock was broken down at $v=20 \mathrm{~m} / \mathrm{s}$ (Fig. 3a) and $v=30 \mathrm{~m} / \mathrm{s}$ (Fig. 3b). Light spots indicate the undisturbed downhole areas. (a)

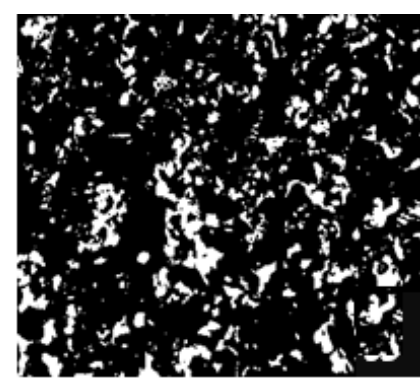

(b)

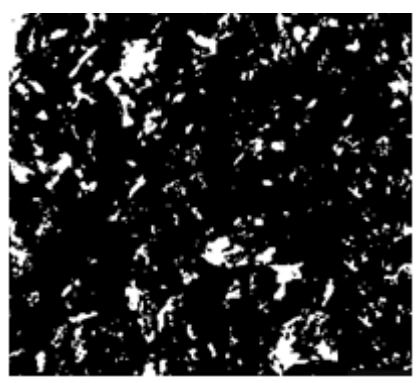

Figure 3. Photos of a model bottomhole of pellet-impact drilling

Efficiency of the rock-breaking ring within the upgraded pellet-impact drilling device may be provided owing to adequate ratios between velocities of the bottomhole advance involving unavoidable formation of its curvilinear periphery and the periphery failure by means of the last ring being that very link supporting optimum drilling velocity. In the majority of cases, the drilling implementation depends upon it.

Expediency of the use of a rock-breaking ring was supported by specific studies defining circumstances of an interaction process between a mechanical breaking member of the pellet-impact device and rock mass. Table 3 represents their basic results.

Analysis of the data, shown in Figure 3, proves that in terms of the modernized pellet-impact drilling, breaking processes are influenced heavily by a value of a pellet load $C$, transferred with the help of a breaking ring, rotation velocity, and the bottomhole condition. Besides, while comparing certain values of penetration velocity of a model bottomhole $u$, stipulated by the changes in various factors, one can observe the following: increase in $u$ intensity depends heavily upon rotation velocity $n$ which growth results in steady $u$ increase. 
Table 3. Basic characteristics and results of interaction between the breaking ring of a pellet-impact device and rock mass

\begin{tabular}{|c|c|c|c|c|c|c|c|c|c|c|}
\hline \multirow{6}{*}{$\begin{array}{l}\text { Rock under } \\
\text { study }\end{array}$} & \multirow{6}{*}{$\begin{array}{c}\text { Condition } \\
\text { of a model } \\
\text { bottomhole }\end{array}$} & \multicolumn{9}{|c|}{ Operating parameters of a rock-breaking process } \\
\hline & & \multicolumn{9}{|c|}{ Axial load on a ring $C, \mathrm{~N} / \mathrm{mm}^{2}$} \\
\hline & & 2 & 3 & 4 & 2 & 3 & 4 & 2 & 3 & 4 \\
\hline & & \multicolumn{9}{|c|}{ Rotation velocity of a ring $n, \min ^{-1}$} \\
\hline & & & 225 & & & 260 & & & 370 & \\
\hline & & \multicolumn{9}{|c|}{ Penetration velocity of a model bottomhole $u, \mathrm{~mm} / \mathrm{min}$} \\
\hline \multirow{2}{*}{$\begin{array}{c}\text { Coarse-grained } \\
\text { granite }\end{array}$} & monolith & 5.36 & 5.49 & 5.66 & 5.65 & 5.86 & 6.03 & 6.52 & 7.03 & 7.16 \\
\hline & disturbed & 6.86 & 7.08 & 7.3 & 7.46 & 7.78 & 8.08 & 8.76 & 9.48 & 9.68 \\
\hline \multirow{2}{*}{$\begin{array}{l}\text { Fine-grained } \\
\text { granite }\end{array}$} & monolith & 3.28 & 3.46 & 3.52 & 3.49 & 3.67 & 3.71 & 4.06 & 4.29 & 4.48 \\
\hline & disturbed & 4.22 & 4.46 & 4.65 & 4.61 & 4.88 & 4.96 & 5.48 & 5.82 & 6.04 \\
\hline
\end{tabular}

The facts are confirmed additionally by the data in Figure 4. The deformed bottomhole condition, demonstrated by its fissures and irregularities, resulting from active action of rock-breaking pellets, will factor into comparatively significant reduction of rock mass strength. Under the conditions, penetration velocity of the model bottomhole $u$ experiences $26-36 \%$ increase. Following stage of the analysis was to identify the effect of the velocity of the device rotation as well as its rock breaking ring and, hence bottomhole characteristics of pellet motion within a bottomhole on the penetration velocity of the well $u$. Figure 4 demonstrates the data.

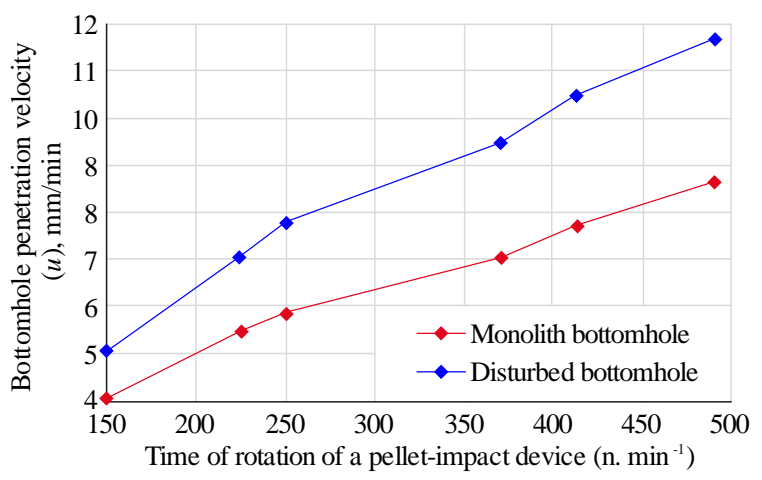

Figure 4. Dependence of the well penetration velocity upon bottomhole conditions of rock breaking

Analysis of the data, represented in Figure 4, helps understand that there is a stable tendency of the growth of bottomhole penetration rate $u$ along with the increasing peripheral rotation velocity and the same frequency for the conditions of rock breaking with the help of pellets (in terms of one or another technical and process procedure). This conclusion confirms the substantiations of the previously formulated statement concerning the possibility to improve a shotbased drilling method by expanding frequency ranges; that was the basis for the modernization of a device for shot drilling of wells represented in Figure 2 [29].

The obtained results also help state that there is the possibility (only in terms of the proposed structural design) to solve some problems of well sinking optimization, i.e.: compensate effectively incomplete values of axial load on rockbreaking pellets by increasing rotation of a device without any geological and technological disturbance of a standard well construction cycle. Formula (4) can be used for rough estimate of the parameters of a mode of modernized pelletimpact drilling; that will give an approximate information concerning the current values of bottomhole advance [30]:

$u_{k}=\frac{V_{p} \cdot M \cdot k_{1}}{\pi \cdot R_{w}^{2}}$, where:

$M$ - amount of pellets passing through a pellet-impact device per time unit;

$k_{1}$ - coefficient taking into account the bottomhole conditions of rock breaking with the help of pellets;

$R_{w}$ - radius of the well being drilled.

According to the data of the performed studies, while designing mode parameters of a modernized device for pellet-impact drilling, $u_{k}$ should correlate with the advance velocity of a mechanical rock-breaking ring to exclude the possibility of the formation of curvilinear peripheral part of the bottomhole with such physical and mechanical characteristics which will be insuperable for a breaking ring.

Attention should be also paid to the facts identified while modelling a process of interaction of a rock-breaking pellet and rock mass; the studies are illustrated by the data represented in Table 4.

Table 4. Estimation data of the interaction process between a rock-breaking pellet and rock mass

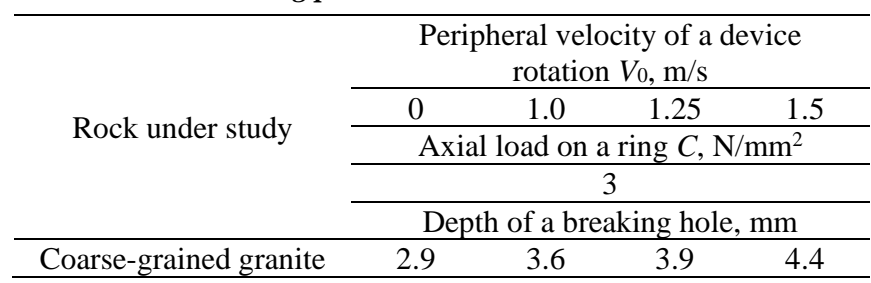

The data in Table 4 demonstrate that the deformation processes in rock mass are stipulated by the nature of implementation of breaking effects. In terms of the available motion of pellets within the bottomhole, it is possible that breaking processes in rock will progress under axial loads being quite lower than the ones in case of static breaking. However, generally such a conclusion requires more thorough analysis and clarification.

Activation of certain properties of washing fluids by using surfactants or their compositions is the most important factor of the intensification of bottomhole breaking processes. That is proved by the experimental data represented in Table 5.

Table 5. Effect of surfactants on the processes of pellet-rock mass interaction

\begin{tabular}{|c|c|c|}
\hline \multirow{5}{*}{ Rock under study } & \multicolumn{2}{|c|}{$\begin{array}{c}\text { Average velocity of the breaking } \\
\text { load application } v, \mathrm{~m} / \mathrm{s}\end{array}$} \\
\hline & 30 & 20 \\
\hline & \multicolumn{2}{|c|}{ Type of a washing liquid } \\
\hline & Technical water & $\begin{array}{c}\text { Technical water } \\
\text { treated with a } \\
\text { surfactant }- \text { sulfonol }\end{array}$ \\
\hline & \multicolumn{2}{|c|}{ Depth of a breaking hole, $\mathrm{mm}$} \\
\hline Coarse-grained granite & 6.2 & 6.2 \\
\hline
\end{tabular}


The effect of surfactant application increases considerably if there are previous deformations (in the form of fractures) on the bottomhole. That is proved by the data from Table 6 .

Table 6. Nature of the surfactant effect on the processes of interaction of pellets and previously deformed rock mass

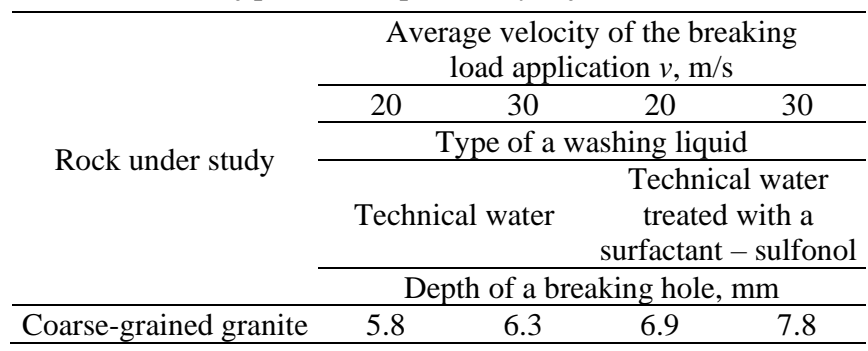

The results of laboratory and analytical studies represented in the paper are the intermediate stage of studying and technical-technological modernization of a hydromechanical drilling method. The theoretical statements and some generalizations represented in the paper require further analysis, specification, and testing, i.e.: it is necessary to identify rational range of sizes of breaking pellets and their motion velocity towards the bottomhole; moreover, it is required to clarify the value of minimally needed and technologically substantiated amount of breaking pellets involved in the formation of different parts of bottomhole zones of a well.

\section{Conclusions}

Comparative analysis has been used to prove positive features of the hydromechanical devices being designed. First of all, that is the possibility to create high degrees of dynamicity of breaking load application on the rock mass. In this context, the latter is characterized by the velocities of pellet impacting from 20 up to $40 \mathrm{~m} / \mathrm{s}$ compared with the similar indices of the roller-bit technique (being the closest one in the very essence of operation) that is not more than $1 \mathrm{~m} / \mathrm{s}$.

The laboratory methods have shown that within the indicated range of pellet-impacting velocities one can observe a regular increase in the penetration depth of breaking deformations by $18-28 \%$ in terms of simultaneous $2.0-2.2$ times growth in the volumes of broken rock - compared with the minimum values; besides, the dependence of breaking processes on the mineralogical properties of rocks has been determined.

According to the studies of the features of breaking processes occurring during the operation of hydrodynamic devices, the correlation of the dependence between geologicalmineralogical and physical properties of rock bottomhole and mode parameters of the well sinking act has been defined. It results in considerable fluctuation of the drilling velocity values. That is characterized as follows: in terms of fixed rotation frequency (peripheral velocity) of a rock-breaking ring of a hydrodynamic device and variable values of its axial load, range of fluctuations of the bottomhole penetration values $u$ is not more than 6-10\%; however, in the contrary case, we observe more considerable increase in $u$ indices up to $20 \%$ and more. That confirms the available factor of close interconnection between the intensity of breaking processes, relative to the proposed technical and technological scheme, and their mode and parametric support.

The availability and nature of the factor of washing fluids activation with the help of surfactants have been identified.
Under the specified experimental conditions, the essence of this factor is shown in the increasing penetration depth of breaking deformations (fractures) by $12-24 \%$.

The obtained analytical and laboratory data are the basis for further design and technological research aimed at the development and wide industrial implementation of a modernized effective method of hydromechanical well drilling with high technical and economic indices. The experimental characteristics of the bottomhole rock-breaking processes are the foundation for the development of rational mode parameters of technological operations for well sinking.

\section{Acknowledgements}

The author expresses his gratitude to the members of the Department of Oil-and-Gas Engineering and Drilling, who participated in a varying degree in the research; the author is especially thankful to Professor O.M. Davydenko for his valuable methodological support.

\section{References}

[1] Lopez, J.C., Lopez, J.E., \& Javier, F. (2017). Drilling and blasting of rocks. London, United Kingdon: CRC Press Taylor \& Francis.

[2] Azar, J.J., \& Robello, S.G. (2007). Drilling engineering. Tulsa, United States: PennWell Books.

[3] Hossain, M.E., \& Islam, M.R. (2018). Drilling engineering: Problems and solutions. Beverly, United States: Scrivener Publishing. https://doi.org/10.1002/9781118998632

[4] Tretiak, A.A., Burenkov, N.N., \& Chikhotkin, A.V. (2013). Rezhushchaia chast dolota PDC optimizatsiia geometricheskikh parametrov. Oil and Gas Journal, (5), 56-58.

[5] Ihnatov, A., Koroviaka, Y., Rastsvietaiev, V., \& Tokar, L. (2021). Development of the rational bottomhole assemblies of the directed well drilling. E3S Web of Conferences, (230), 01016. https://doi.org/10.1051/e3sconf/202123001016

[6] Zhang, Z.X. (2016). Rock fracture and blasting. Theory and applications. London, United States: Elsevier. https://doi.org/10.1016/B978-012-802688-5.00003-8

[7] Robello, S.G., \& Xiushan, L. (2009). Advanced drilling engineering. Houston, United States: Gulf Publishing Company.

[8] Tretiak, A.A., Savenok, O.V., Grossu, A.N., \& Borisov, K.A. (2015). Novoe dvukhieiarusnoe doloto rezhushchego tipa. Oil and Gas Journal, (5), 50-53.

[9] Ihnatov, A.A. (2020). Do pytannia vyznachennia vybiinykh robochykh kharakterystyk prystroiv hidromekhanichnoho burinnia. Tooling materials Science, (23), 78-88.

[10] Bellin, F. (2010). The current state of PDC bit technology. World Oil, (9), 41-42.

[11] Davidenko, A., \& Ihnatov, A. (2013). Abrazivno-mehanicheskoe udarnoe burenie skvazhin. Dnipropetrovsk, Ukraina: Natsionalnyi Gornyi Universitet.

[12] Hossain, M.E., \& Al-Majed, A.A. (2015). Fundamentals of sustainable drilling engineering. Beverly, United States: Scrivener publishing. https://doi.org/10.1002/9781119100300

[13] Kovalev, A., Ryabchikov, S., Aliev, F., Yakushev, D., \& Gorbenko, V. (2015). Problemyi gidrodinamicheskih sposobov bureniya skvazhin i osnovnyie napravleniya dlya ih resheniya. Bulletin of the Tomsk Polytechnic University, 326(3), 6-12.

[14] Gatlin, C. (1960). Petroleum engineering: Drilling and well completions. New York, United States: Prentice-Hall, INC, Englewood Cliffs.

[15] Ihnatov, A., \& Viatkin, S. (2013). Impact drill for well drilling. Patent No. 102707. Kyiv, Ukraine.

[16] Ihnatov, A. (2016). Device for shot drilling. Patent No. 111350. Kyiv, Ukraine.

[17] Moisyshyn, V., Borysevych, B., \& Sheherbiy, R. (2013). Mulifactorial mathematical model of mechanical drilling speed. Annual ScientificTechnical Collection - Mining of Mineral Deposits, 359-368. https://doi.org/10.1201/b16354-65

[18] Mysliuk, M.A. (2010). Modeliuvannia pryiniattia tekhnolohichnykh rishen u burinni. Oil and Gas Industry, (3), 11-15.

[19] Curry, G.L., \& Feldman, R.M. (2012). Manufacturing systems. Modeling and analysis. Berlin, Germany: Springer. https://doi.org/10.1007/978-3642-16618-1 
[20] Datta, S., \& Davim, J.P. (2019). Optimization in industry. Berlin, Germany: Springer. https://doi.org/10.1007/978-3-030-01641-8

[21] Hossain, M.E. (2016). Fundamentals of drilling engineering. Beverly, United States: Scrivener Publishing. https://doi.org/10.1002/9781119083931

[22] Vaddadi, N. (2015). Introduction to oil well drilling. New York, United States: Bathos.

[23] Davidenko, A.N., Ratov, B.T., Pashchenko, A.A., \& Ihnatov, A.A (2018). Vliyaniye gidrostaticheskogo davleniya na udarnoye abrazivno-mekhanicheskoye bureniye skvazhin Almaty, Kazakhstan: Caspian Public University.

[24] Speight, J.G. (2018). Formulas and calculations for drilling operations. Beverly, United States: Scrivener Publishing. https://doi.org/10.1002/9781119083689

[25] Gabolde, G., \& Nguyen, J.P. (2006). Drilling. Paris, France: Editions Technips publishing.
[26] Tretiak, A.A., Sysoev, N.I., \& Burenkov N.N. (2012). Raschet konstruktivnykh parametrov burovykh koronok armirovannykh PDC. Oil and Gas Journal, (5,) 66-69.

[27] Kovalyov, A.V., Ryabchikov, S.Ya., Isaev, Ye.D., Aliev, F.R., Gorbenko, M.V., \& Strelnikova, A.B. (2015). Designing the ejector pellet impact drill bit for hard and tough rock drilling. IOP Conferense Series: Earth and Environmental Science, (24), 20-20. https://doi.org/10.1088/1755-1315/24/1/012016

[28] Nguyen, J.P. (1996). Drilling. Oil and gas field development techniques. Paris, France: Editions Technips publishing.

[29] Rabia, H. (1986). Oilwell drilling engineering: Principles and practice. Berlin, Germany: Springer.

[30] Uvakov, A. (1969). Sharostruynoe burenie. Moskva, Rossiya: Nedra.

\section{Дослідження механіки процесу руйнування гірських порід в умовах гідромеханічного буріння}

\section{А. Ігнатов}

Мета. Обгрунтування конструктивних і технологічних параметрів модернізованих пристроїв гідромеханічного буріння, виходячи зі встановлених особливостей процесу взаємодії руйнівних куль із породним масивом.

Методика. Дослідження особливостей спрямованості та ходу протікання вибійних процесів руйнування гірського масиву, виконано із застосуванням сучасних методів аналітичного аналізу й експериментально-лабораторних досліджень, зокрема шляхом використання окремих прийомів математичного та фізичного моделювання, методик теоретичної обробки та інтерпретації результатів досліджень у середовищі SolidWorks, Statgraphics, Mathcad і низки відповідних контрольно-вимірювальних приладів та матеріалів. Свердловинні вибійні породоруйнівні процеси у своїй технологічній послідовності моделювались на спеціальному дослідницькому лабораторному стенді, обладнаному контрольно-вимірювальним блоком (зокрема, витратоміром, манометром, тахометром, координатником).

Результати. Доведено перспективність застосування комбінованих способів руйнування гірських порід. Запропоновано конструктивні схеми модернізованих пристроїв для буріння свердловин. Вивчено ознаки кулеструминного буріння 3 позицій наявності в нього значної динамічної складової у процесах руйнування гірського масиву. 3'ясовано характер впливу швидкості прикладення руйнівного навантаження на результати вибійних деформаційних процесів. Доведено ефективність запропонованої схеми модернізації кулеструминного буріння, що базується на максимальному використанні особливостей стану деформованого кулями вибою свердловини. Розглянуто заходи щодо підвищення техніко-технологічних показників дробового буріння. Окреслені вимоги до умов забезпечення сталості роботи породоруйнівного кільця кулеструминного пристрою. Перераховані напрями подальших досліджень.

Наукова новизна. Встановлено, що показником надійності роботи пристроїв гідромеханічного буріння є дотримання у їх конструкціях і технологічних схемах застосування цілком певних геометричних та параметричних співвідношень, що відповідають стійкому режиму поглиблення свердловини.

Практична значимість. Отримані результати стендових і аналітичних досліджень можуть бути покладені в основу створення ефективної технології гідромеханічного буріння свердловин з високими техніко-економічними показниками. Дані 3 вивчення вибійних породоруйнівних процесів $\epsilon$ базовими для розробки раціональних режимних параметрів процесу поглиблення свердловин.

Ключові слова: свердловина, порода, буріння, вибій, частота обертання, швидкість поглиблення

\section{Исследование механики процесса разрушения горных пород в условиях гидромеханического бурения}

\section{А. Игнатов}

Цель. Обоснование конструктивных и технологических параметров модернизируемых устройств гидромеханического бурения, исходя из установленных особенностей процесса взаимодействия разрушающих шаров с породным массивом.

Методика. Исследование особенностей направленности и хода протекания забойных процессов разрушения горного массива выполнено с применением современных методов аналитического анализа и экспериментально-лабораторных исследований, а именно путем использования отдельных приемов математического и физического моделирования, методик теоретической обработки и интерпретации результатов исследований в среде SolidWorks, Statgraphics, Mathcad и ряда соответствующих контрольноизмерительных приборов и материалов. Скважинные забойные породоразрушающие процессы в своей технологической последовательности моделировались на специальном исследовательском лабораторном стенде, оборудованном контрольно-измерительным блоком (в частности, расходомером, манометром, тахометром, координатником).

Результаты. Доказана перспективность применения комбинированных способов разрушения горных пород. Предложены конструктивные схемы модернизируемых устройств для бурения скважин. Изучены особенности шароструйного бурения с позиций наличия у него значительной динамической составляющей в процессах разрушения горного массива. Выяснен характер влияния скорости приложения разрушающей нагрузки на результаты забойных деформационных процессов. Доказана эффективность предложенной схемы модернизации шароструйного бурения, базирующейся на максимальном использовании особенностей состояния деформированного шарами забоя скважины. Рассмотрены мероприятия, повышающие технико-технологические показатели дробового бурения. Обозначены требования к условиям обеспечения устойчивости работы породоразрушающего кольца шароструйного устройства. Перечислены направления дальнейших исследований.

Научная новизна. Установлено, что показателем надежности работы устройств гидромеханического бурения является соблюдение в их конструкциях и технологических схемах применения вполне определенных геометрических и параметрических соотношений, отвечающих устойчивому режиму углубки скважины.

Практическая значимость. Полученные результаты стендовых и аналитических исследований могут быть положенные в основу создания эффективной технологии гидромеханического бурения скважин с высокими технико-экономическими показателями. Данные по изучению забойных породоразрушающих процессов являются базовыми для разработки рациональных режимных параметров процесса углубки скважин.

Ключевые слова: скважина, порода, бурение, забой, частота вращения, скорость углубки 